\section{PKM PENANAMAN NILAI KARAKTER MELALUI MASA TAARUF SISWA MADRASAH DALAM KONDISI NORMAL BARU COVID-I 9 DI MA PLUS NURUL ISLAM SEKARBELA}

Dedi Riyan Rizaldi', Muhamad Zaenudin², Fakhrurrozi ${ }^{3}$, Ziadatul Fatimah $^{4}$

1,2,3 MA Plus Nurul Islam Sekarbela
${ }^{4}$ SMA NW Mataram

* Dedi Riyan Rizaldi

Email: dedi0313@gmail.com

\begin{abstract}
Research has been carried out which aims to determine the implementation of introducing the madrasa environment to prospective new students through the activities of the Ta'aruf Period of Madrasah Students. This study uses a qualitative approach with the method of observation. This research was conducted on all prospective new students of MA Plus Nurul Islam Sekarbela for the academic year 202 I/2022, with a total of 45 people. The implementation of the research went through two stages, namely the delivery of material and the introduction of the madrasa environment. Based on the results of observations and discussions, it can be seen that the activities of the Madrasah Student Ta'aruf Period are essential for prospective new students to get to know more about the conditions, characteristics, and environment of the madrasa. In addition, this activity instills various character values of madrasah children through various activities that are integrated with religious contexts to meet the goals set previously.

Keywords: Character Value, Ta'aruf Period of Madrasah Students, Madrasah Environment
\end{abstract}

\begin{abstract}
Abstrak
Telah dilakukan penelitian yang bertujuan untuk mengetahui pelaksanaan kegiatan proses pengenalan lingkungan madrasah kepada peserta didik baru melalui kegiatan Masa Taaruf Siswa Madrasah. Penelitian ini menggunakan pendekatan kualitatif dengan metode observasi. Penelitian ini dilakukan kepada seluruh peserta didik baru MA Plus Nurul Islam Sekarbela Tahun Pelajaran 202 I/2022 dengan jumlah 45 orang. Pelaksanaan penelitian melalui dua tahapan yaitu penyampaian materi dan pengenalan lingkungan madrasah. Berdasarkan hasil observasi dan pembahasan dapat diketahui bahwa kegiatan masa Taaruf Siswa Madrasah sangat diperlukan bagi peserta didik baru untuk mengenal lebih jauh terkait kondisi, karakterstik, dan lingkungan madrasah. Selain itu kegiatan ini menanamkan berbagai nilai karakter anak madrasah melalui berbagai kegiatan yang diintegrasikan dengan konteks keagamaan sehingga sesuai dengan tujuan yang ditetapkan sebelumnya..

Kata Kunci: Nilai Karakter, Masa Ta'aruf Siswa Madrasah, Lingkungan Madrasah
\end{abstract}


PKM Penanaman Nilai Karakter melalui masa Taaruf Siswa Madrasah dalam kondisi Normal Baru Covid-19 di MA Plus Nurul Islam Sekarbela

Dedi Riyan Rizaldi, Muhamad Zaenudin, Fakhrurrozi, Ziadatul Fatimah

Volume 1, No. 2, Agustus 2021 hal. 195-201

DOI Artikel : 10.46306/jub.v1i2.36

\section{PENDAHULUAN}

Proses pembelajaran merupakan suatu hal yang sifatnya berkesinambungan menuju tingkatan yang lebih tinggi. Proses perubahan tersebut tentunya akan dialami setiap peserta didik yang telah selesai melalui proses pembelajaran pada tahap sebelumnya (Rizaldi, et al., 2020). Dengan terjadinya perubahan baik itu terkait kondisi, sistem, dan aspek lainnya maka akan sangat penting bagi peserta didik untuk melalui suatu proses pengenalan lingkungan yang baru. Lingkungan dapat mempengaruhi masa perkembangan setiap individu kedepannya. Setiap individu memiliki sikap yang berbeda dalam hal beradaptasi dengan lingkungan sekitarnya (Rohmah, 2016). Sebagian besar individu ada yang dapat dengan mudah beradaptasi dengan kondisi barunya, namun ada juga individu yang memerlukan waktu lebih lama (Hazin, et al., 202I; Rizaldi, et al., 202 la; Tirtoni, 2020). Proses pengenalan dan penyesuaian peserta didik terkait lingkungan baru biasa disebut dengan kegiatan Masa Ta'aruf Siswa Madrasah (MATSAMA).

Kegiatan ini merupakan agenda yang dilaksanakan setiap tahun pelajaran baru dan diperuntukkan bagi peserta didik baru. Tujuan dilakukannya kegiatan ini untuk memperkenalkan kepada peserta didik tentang tata cara pembelajaran, karakter, sikap, dan kebiasaan yang terdapat di lingkungan madrasah. Hanya saja saat ini pandemi COVID-19 masih menjadi bagian yang tidak terpisahkan dari berbagai aktivitas manusia dalam kehidupan sehari-hari (Mayanty, et al., 202I; Rizaldi \& Fatimah, 2020). Kondisi ini membatasi tidak hanya dalam proses interaksi antara manusia di lingkungan tempat tinggal, namun juga membatasi berbagai kegiatan yang terjadi di madrasah. Pembatasan tersebut pada dasarnya bertujuan sangat baik yaitu untuk membatasi penyebaran COVID-19 di lingkungan madrasah.

Kegiatan MATSAMA pada Tahun Pelajaran 2021/2022 mengalami sedikit perubahan, dimana pada tahun ini kondisi proses pembelajaran masih terkendala karena pandemi COVID-19. Perubahan tersebut merujuk pada Surat Keputusan Kemenag No. B-I829/DJ.I/Dt.I.I/HM.01/06/202I tentang Pelaksanaan Masa Ta'aruf Siswa Madrasah (MATSAMA) Tahun Pelajaran 2021/2022. Sehingga perlu dilakukan proses penyesuaian kegiatan untuk meminimalisir terjadinya interaksi antara peserta didik baru. Menindaklanjuti kondisi tersebut maka dalam pelaksanaan kegiatan MATSAMA tahun ini, pihak madrasah menerapkan dua sistem dalam proses pelaksanaanya. Sistem pertama dengan menerapkan strategi berupa pemanfaatan media seperti WhatsApps Group (WAG) sebagai selama proses penyampaian materi yang sifatnya umum. Sedangkan sistem kedua saat proses pengenalan kondisi madrasah dilakukan secara tatap muka dengan tetap memperhatikan protokol kesehatan.

\section{METODE PENGABDIAN}

Penelitian ini berfokus pada kegiatan madrasah dalam mengenalkan kondisi lingkungan MA Plus Nurul Islam dan menanamkan nilai karakter peserta didik baru. Pendekatan dalam penelitian ini menggunakan pendekatan kualitatif yaitu termasuk dalam jenis penelitian lapangan (Field Research), dengan berfokus pada metode observasi. Metode ini berfokus untuk mengkaji dan mendeskripsikan kegiatan Masa 
PKM Penanaman Nilai Karakter melalui masa Taaruf Siswa Madrasah dalam kondisi Normal Baru Covid-19 di MA Plus Nurul Islam Sekarbela

Dedi Riyan Rizaldi, Muhamad Zaenudin, Fakhrurrozi, Ziadatul Fatimah

Volume 1, No. 2, Agustus 2021 hal. 195-201

DOI Artikel : 10.46306/jub.v1i2.36

Ta'aruf Siswa Madrasah (MATSAMA) yang dilakukan MA Plus Nurul Islam pada Tahun Pelajaran $2021 / 2022$.

Kegiatan Masa Ta'aruf Siswa Madrasah (MATSAMA) dilakukan melalui dua tahapan yaitu penyampaikan materi dan pengenalan lingkungan madrasah mulai dari tanggal I4 - 15 Juli 202I di lingkungan MA Plus Nurul Islam Sekarbela. Sasaran dalam kegiatan ini adalah semua peserta didik baru MA Plus Nurul Islam Sekarbela yang berjumlah 45 orang. Tahap penyampaikan materi dilakukan dengan memberikan video dan Power Point (PPT) kepada peserta didik untuk dipelajari dari rumah (berbasis dalam jaringan), sedangkan tahap wawancara minat, bakat, dan pengenalan lingkungan madrasah dilakukan secara langsung melalui dua shift (kelompok waktu) dengan tetap memperhatikan protokol kesehatan sesuai dengan surat edaran yang diterbitkan .

\section{PELAKSANAAN DAN PEMBAHASAN}

\section{a. Penanaman Nilai Karakter}

Karakter menurut bahasa merupakan bawaan, kepribadian, budi pekerti, perilaku, dan sifat yang ada pada diri seseorang. Karakter juga mengacu kepada serangkaian perilaku (behaviors), sikap (attitudes), motivasi (motivations), dan keterampilan (skills) (Gunawan, 20I2; Supriyanto, 2020; Tirtoni, 2020). Lebih spesifiknya, karakter merupakan nilai-nilai perilaku manusia yang berhubungan dengan Tuhan Yang Maha Esa, diri sendiri, sesama manusia, lingkungan, dan kebangsaan yang terwujud dalam pikiran, sikap perasaan, perkataan, dan perbuatan, berdasarkan norma-norma agama, hukum, tata krama, budaya dan adat istiadat.

Pendidikan karakter sebagaimana diketahui telah menjadi suatu pembelajaran penting di setiap sekolah (Hendriana \& Jacobus, 2017; Tanis, 2013). Dalam pendidikan karakter di sekolah, semua komponen (pemangku pendidikan) harus dilibatkan, termasuk komponen-komponen pendidikan itu sendiri, yaitu isi kurikulum, proses pembelajaran, penilaian, pengelolaan sekolah, dan aktivitas lainnya yang berkaitan dengan pendidikan karakter. Di samping itu, pendidikan karakter dimaknai sebagai suatu perilaku warga sekolah yang dalam menyelenggarakan pendidikan harus berkarakter. Adapun yang dimaksud berkarakter adalah berkepribadian, berperilaku, bersifat, bertabiat, dan berwatak yang baik.

Dengan pendidikan karakter yang diterapkan secara sistematis dan berkelanjutan yang bisa dibangun dalam lingkungan sekolah akan membuat anak menjadi cerdas secara mental dan emosional (Ekowati \& Utomo, 2019). Kecerdasan emosinal ini adalah bekal penting dalam mempersiapkan anak menyongsong masa depan, karena seseorang akan lebih mudah dan berhasil menghadapi segala macam tantangan kehidupan, termasuk tantangan untuk berhasil secara akademis. Terdapat sembilan pilar karakter yang perli dibiasakan dan dimiliki oleh setiap individu (Erfayliana, 20I5), yaitu:

I. Cinta Tuhan dan segenap ciptaan-Nya

2. kemandirian dan tanggungjawab

3. kejujuran/amanah, diplomatis

4. hormat dan santun 
PKM Penanaman Nilai Karakter melalui masa Taaruf Siswa Madrasah dalam kondisi Normal Baru Covid-19 di MA Plus Nurul Islam Sekarbela

Dedi Riyan Rizaldi, Muhamad Zaenudin, Fakhrurrozi, Ziadatul Fatimah

Volume 1, No. 2, Agustus 2021 hal. 195-201

DOI Artikel : 10.46306/jub.v1i2.36

5. dermawan, suka tolong-menolong dan gotong royong/Kerjasama

6. percaya diri dan pekerja keras

7. kepemimpinan dan keadilan

8. baik dan rendah hati

9. toleransi, kedamaian, dan kesatuan.

Kesembilan pilar karakter tersebut, diajarkan dan diterapkan secara sistematis kepada peserta didik. Pentingnya penanaman karakter adalah segala sesuatu yang dilakukan oleh pendidik, karena seorang pendidik mampu mempengaruhi karakter peserta didik dengan baik sesuai dengan pedoman yang berlaku. Guru sebagai fasilitator dan motivator dalam membentuk watak peserta didik. Hal ini mencakup keteladanan dalam berperilaku, bertutur kata, bertoleransi, dan berbagai hal terkait lainnya.

Pendidikan karakter memiliki esensi dan makna yang sama dengan pendidikan moral dan pendidikan akhlak (Marzuki \& Hakim, 2019) yang memiliki tujuan dalam membentuk pribadi peserta didik, supaya menjadi manusia yang baik. Sehingga, hakekat dari pendidikan karakter dalam konteks pendidikan khususnya di negara Indonesia sendiri yaitu pedidikan nilai, yakni pendidikan nilai-nilai luhur yang bersumber dari budaya bangsa Indonesia sendiri (Rizaldi et al., 202 Ic), dalam rangka membina kepribadian generasi muda.

\section{b. Masa Ta'aruf Siswa Madrasah (MATSAMA)}

Kegiatan Masa Ta'aruf Siswa Madrasah merupakan suatu kegiatan rutin yang dilakukan setiap madrasah untuk memfasilitasi peserta didik baru untuk memberikan gambara secara umum terkait situasi pembelajaran dan kondisi madrasah. Sehingga dari kegiatan MATSAMA ini diharapkan mampu menentukan tingkat keberhasilan yang dialami peserta didik baru selama proses pembelajaran di Madrasah pada masa selanjutnya. Karena konteks kegiatan MATSAMA adalah untuk menanamkan dan memperkalkan kondisi baru, maka semua kegiatan yang akan dilakukan oleh peserta didik harus bersifat edukatif.

Menurut Peraturan Menteri Pendidikan dan Kebudayaan Nomor 18 Tahun 2016 tentang pengenalan lingkungan madrasah bagi siswa baru menekankan bahwa kegiatan tersebut harus mampu memberikan pengalaman yang menyenangkan kepada para peserta didik baru dan mampu menumbuhkan kreativitas dan inovasi kedepannya. Selain itu kegiatan MATSAMA didasarkan pada visi dan misi Direktorat Kurikulum Sarana Kelembagaan dan Kesiswaan Madrasah, Ditjen Pendidikan Islam, Kementerian Agama Republik Indonesia, yaitu mencetak generasi yang tidak hanya cerdas akal, tetapi juga kemampuan yang baik secara spiritual dan berkarakter kebangsaan.

\section{c. Implementasi Kegiatan MATSAMA di MA Plus Nurul Islam}

Kegiatan MATSAMA mulai dilaksanakan pada Rabu, I4 Juli 202I melalui sistem daring menggunakan platform WhatsApps Grup (WAG) dengan kegiatan penyampaian materi terkait profil, struktur, tenaga pendidik dan kependidikan MA Plus Nurul Islam (materi pertama), sistem KBM dan sosialisasi penjurusan (materi kedua), serta bernalar kritis dan kompetitif (materi ketiga). Bahan 
PKM Penanaman Nilai Karakter melalui masa Taaruf Siswa Madrasah dalam kondisi Normal Baru Covid-19 di MA Plus Nurul Islam Sekarbela

Dedi Riyan Rizaldi, Muhamad Zaenudin, Fakhrurrozi, Ziadatul Fatimah

Volume 1, No. 2, Agustus 2021 hal. 195-201

DOI Artikel : 10.46306/jub.v1i2.36

materi ini diberikan dengan tujuan untuk memperkenalkan terkait berbagai komponen yang terdapat di lingkungan MA Plus Nurul Islam serta kemampuan yang perlu dikembangkan dan dimiliki oleh setiap peserta didik selama melakukan proses pembelajaran. Hal tersebut perlu ditekankan kepada peserta didik baru karena akan menjadi bagian dari proses yang dialami selama melakukan kegiatan belajar mengajar di MA Plus Nurul Islam.

Kegiatan hari pertama dibatasi menggunakan sistem daring (dalam jaringan) melalui proses belajar mandiri. Penanaman nilai tanggung jawab dan kejujuran merupakan hal yang sangat ditekankan pada penyelenggaraan MATSAMA di hari pertama. Selain itu pihak madrasah tetap berkomunikasi dengan wali peserta didik baru untuk tetap memantau dan mendampingi anak selama melakukan proses MATSAMA. $\mathrm{Hal}$ tersebut dikarenakan beberapa faktor antara lain: I). Anak belum mampu memanajemen waktu belajar mandiri dengan maksimal, 2). Orang tua mengetahui kemampuan anak dalam mempelajari hal-hal baru, 3). Sebagai penghubung antara pihak madrasah dengan anak, dan 4). Mengawasi penggunaan gadget agar tepat dan sesuai kebutuhan (Handayani dalam Rizaldi, et al., 202lb). Untuk mengetahui dan menindaklanjuti bahan materi yang sudah berikan, maka peserta didik baru akan mengisi sebuah form yang berkaitan dengan profil, struktur, tenaga pendidik dan kependidikan MA Plus Nurul Islam. Menurut Daryanto (2010) bahwa kegiatan evaluasi sangat perlu dilakukan untuk mendapatkan informasi yang akurat mengenai tingkat pencapaian tujuan yang sudah diharapkan sebelumnya sehingga akan muncul upaya tidak lanjut kedepannya (dalam Ratmawulan \& Rusdiana, 2014). Berdasarkan hasil form yang sudah dijawab oleh peserta didik baru maka panitia MATSAMA dapat menilai sejauh mana materi dapat dipahami selama melakukan proses belajar mandiri.

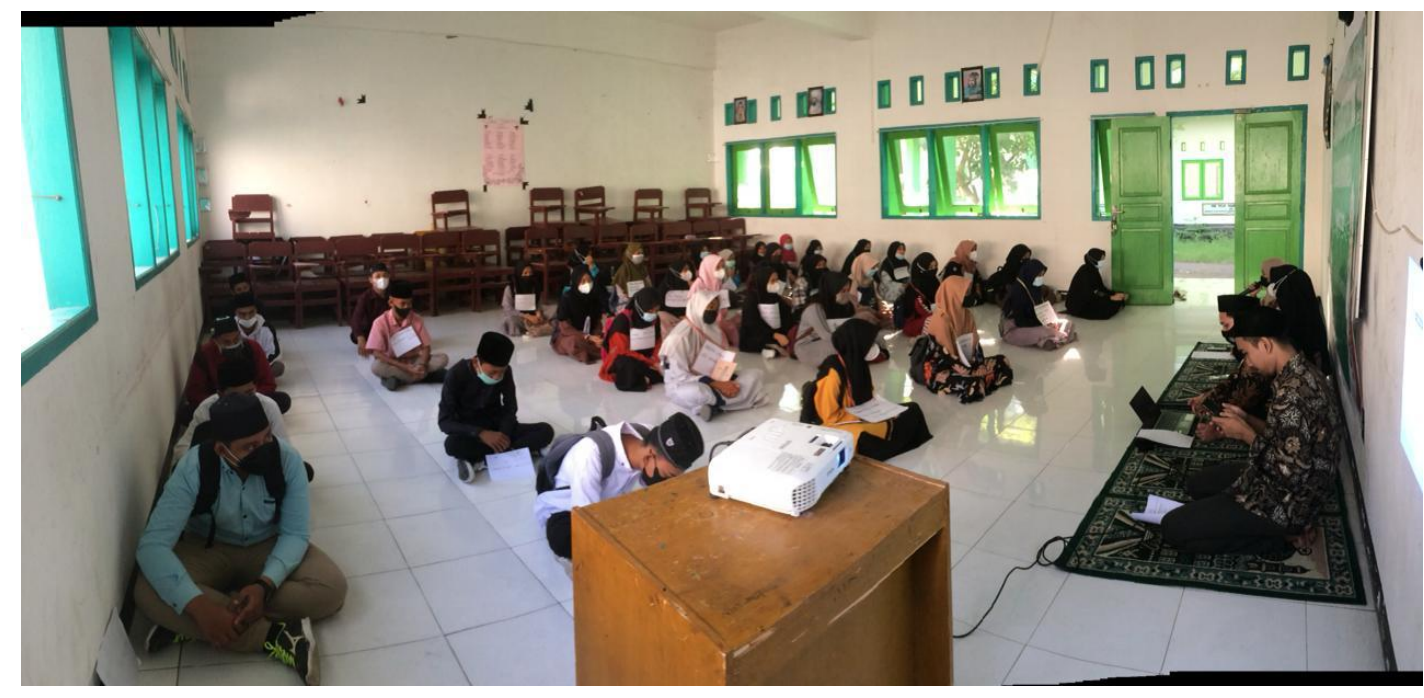

Gambar I. Kegiatan Renungan dan Penguatan Nilai Karakter kepada Peserta Didik Baru

Kegiatan hari kedua dilaksanakan pada Kamis, 15 Juli 2021 yang dilakukan melalui proses tatap muka di lingkungan MA Plus Nurul Islam dengan tetap menerapkan protokol kesehatan. Kegiatan diawali dengan penyampaian materi terkait Ta'lim Muta'alim dan Moderasi Beragama (Ukhuwah Islamiyah, Ukhuwah Basyariyah, Ukhuwah Wathoniyah) oleh Ustad H. Fakhrurrozi, Lc., M.Sy., dan Ustad H. Zulaifi 
PKM Penanaman Nilai Karakter melalui masa Taaruf Siswa Madrasah dalam kondisi Normal Baru Covid-19 di MA Plus Nurul Islam Sekarbela

Dedi Riyan Rizaldi, Muhamad Zaenudin, Fakhrurrozi, Ziadatul Fatimah

Volume 1, No. 2, Agustus 2021 hal. 195-201

DOI Artikel : 10.46306/jub.v1i2.36

AMZ, Lc. Materi ini sangat perlu disampaikan secara langsung karena menjadi pegangan awal oleh peserta didik baru terkait karakter dan sifat yang harus dimiliki oleh seorang santri dan santriwati selama menuntut ilmu di MA Plus Nurul Islam. Dengan membiasakan peserta didik untuk intropeksi diri selama melaksanakan kegiatan MATSAMA, maka diharapkan karakter peserta didik baru dapat terbentuk dan siap untuk melalui proses pembelajaran menjadi peserta didik MA Plus Nurul Islam Sekarbela.

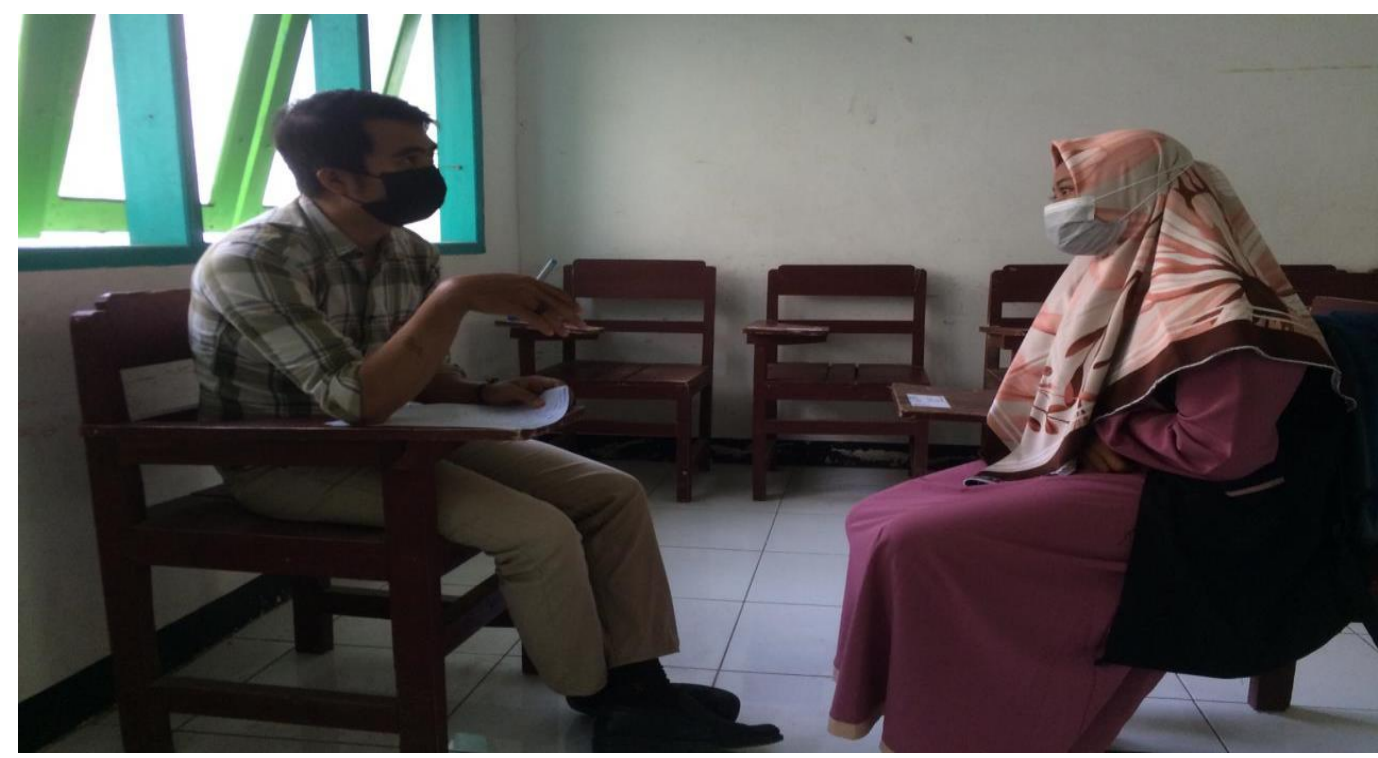

Gambar 2. Proses Pendampingan Pengenalan Lingkungan Madrasah untuk Peserta Didik Baru

Kegiatan terakhir yang dilakukan oleh peserta didik baru adalah proses pengenalan lingkungan madrasah yang didampingi oleh panitia kegiatan MATSAMA MA Plus Nurul Islam Tahun Pelajaran 202I/2022. Berdasarkan kegiatan yang sudah dilakukan oleh peserta didik baru selama kurang lebih dua hari, didapatkan bahwa respon peserta didik dan wali murid sangat positif terkait diadakannya kegiatan MATSAMA yang diselenggarakan oleh madrasah. Wali murid beranggapan bahwa kegiatan seperti ini sangat perlu dilakukan karena setiap peserta didik baru berasal dari lingkungan yang berbeda. Perbedaan sifat dan karakteristik ini tentunya jika tidak segera disamakan persepsi akan sangat mempengaruhi pelaksanaan proses pembelajaran dikemudian hari. Menurut Bachtiar (2020), bahwa dengan adanya persepsi yang sama di antara peserta didik akan semakin mempermudah baik bagi guru dan peserta didik selama melaksanakan proses pembelajaran.

\section{KESIMPULAN DAN SARAN}

Berdasarkan hasil penelitian dan pembahasan didapatkan bahwa Masa Ta'aruf Siswa Madrasah (MATSAMA) merupakan kegiatan awal yang perlu dilakukan setiap madrasah untuk menyambut dan memperkenalkan lingkungan madrasah kepada seluruh peserta didik baru. Kegiatan ini memberikan banyak pemahaman baru yang dijadikan sebagai pegangan awal oleh peserta didik dalam proses pembelajaran pada tahap selanjutnya. Berdasarkan kegiatan yang sudah dilakukan diharapkan peserta didik 
PKM Penanaman Nilai Karakter melalui masa Taaruf Siswa Madrasah dalam kondisi Normal Baru Covid-19 di MA Plus Nurul Islam Sekarbela

Dedi Riyan Rizaldi, Muhamad Zaenudin, Fakhrurrozi, Ziadatul Fatimah

Volume 1, No. 2, Agustus 2021 hal. 195-201

DOI Artikel : 10.46306/jub.v1i2.36

baru mampu secepatnya terbiasa dan beradaptasi dengan berbagai kondisi, karakteristik, dan lingkungan madrasah sehingga mampu berprestasi dan memiliki karakter yang baik.

\section{DAFTAR PUSTAKA}

Bachtiar, T. (2020). Pengaruh Persepsi Siswa Mengenai Kompetensi Profesional dan Pedagogik Guru terhadap Motivasi dan Hasil Belajar Biologi Siswa MTs Sultan Hasanudin. Jurnal Nalar Pendidikan, 8(2): I47-I53.

Ekowati, U., Nggonggoek, W., \& Utomo, S. S. (2019). Sosialisasi pendidikan karakter berbasis budaya pada anak-anak dengan media video. Selaparang Jurnal Pengabdian Masyarakat Berkemajuan, 2(2), 19-23.

Erfayliana, Y. (2015). Pendidikan Jasmani Dalam Membentuk Etika, Moral, dan Karakter. TERAMPIL: Jurnal Pendidikan dan Pembelajaran Dasar, 2(2), 302-3I 5.

Gunawan , H. (20I2). Pendidikan Karakter Konsep dan Implementasi. Bandung: Alfabeta

Hazin, M., Hidayat, S., Tanjung, A. S., Syamwiel, A., \& Hakim, A. (202I). PENDAMPINGAN PSIKOSOSIAL DAN MODUL PEMBELAJARAN SEKOLAH DASAR UNTUK MENGATASI LEARNING LOSS. Jubaedah: Jurnal Pengabdian dan Edukasi Sekolah (Indonesian Journal of Community Services and School Education), I(2), I78-I89.

Hendriana, E. C., \& Jacobus, A. (20I7). Implementasi pendidikan karakter di sekolah melalui keteladanan dan pembiasaan. JPDI (Jurnal Pendidikan Dasar Indonesia), I (2), 25-29.

Marzuki, I., \& Hakim, L. (2019). Strategi Pembelajaran Karakter Kerja Keras. Rausyan Fikr: Jurnal Pemikiran dan Pencerahan, I5(I).

Mayanty, S., Rusmana, I. M., \& Nurrahmah, A. (202I). STRATEGI MENJADI GURU INSPIRATIF DI MASA PANDEMI : (PKM DI TK DAN SDI AL KAUTSAR BINTARO SCHOOL). Jubaedah: Jurnal Pengabdian dan Edukasi Sekolah (Indonesian Journal of Community Services and School Education), I(I), $I-I I$.

Rizaldi, D. R., \& Fatimah, Z. (2020). How the Distance Learning can be a Solution during the Covid-19 Pandemic. International Journal of Asian Education, I (3), I I7-I 24.

Rizaldi, D. R., Fatimah, Z., Hasanah, M., Faisal, F., \& Handayani, S. (2020). Pembelajaran Berbasis Berugak Pintar Untuk Meningkatkan Minat Belajar Anak di Desa Dasan Lekong. Jurnal Pengabdian Masyarakat Sains Indonesia, 2(2).

Rizaldi, D. R., Doyan, A., Makhrus, M., Fatimah, Z., \& Nurhayati, E. (202 Ia). Adaptation to New Normal Conditions: Students Physics Learning Outcomes Using the Blended Learning Model. International Journal of Asian Education, 2(3), 369-376.

Rizaldi, D. R., Nurhayati, E., Fatimah, Z., \& Amni, Z. (202 lb). The Importance of Parental Assistance in Supervising the Use of Technology for Children During the Home Learning Program. International Journal of Engineering, Science and Information Technology, I (3), 7-I0.

Rizaldi, D. R., Andayani, Y., Doyan, A., Makhrus, M., Fatimah, Z., \& Nurhayati, E. (202 Ic). The use of Betel leaf in Nyirih tradition: Analyzing an ethnoscience-based learning material. International Journal on Education Insight, 2(I), 29-36.

Rohmah, L. S. (2016). Adaptasi Dan Penerimaan Diri Penerima Manfaat Di Balai Pelayanan Sosial Asuhan Anak "Budhi Sakti" Banyumas Laila Septiana Rohmah NIM. 1223101010 (Doctoral dissertation, IAIN).

Supriyanto, E. E. (2020). Kontribusi Pendidikan Pesantren Bagi Pendidikan Karakter di Indonesia. Jurnal Pendidikan Nusantara, I ( I), I3-26.

Tanis, H. (20/3). Pentingnya pendidikan character building dalam membentuk kepribadian mahasiswa. Humaniora, 4(2), 1212-1219.

Tatminingsih, S. (2019). Alternatif Stimulasi Kemampuan Kognitif melalui Penerapan Model Pembelajaran Berbasis Permainan Komprehensif. Jurnal Obsesi: Jurnal Pendidikan Anak Usia Dini, 3(I), I83-190.

Tirtoni, F. T. F. (2020). Internalisasi Model Pendidikan Karakter Melalui Leadership Sosial Preneur Pada Pendidikan Dasar Untuk Menuju Revolusi Industri 4.0 Indonesia Berkemajuan. EduStream: Jurnal Pendidikan Dasar, 4(I), 73-85.

Ratmawulan, E., \& Rusdiana. (20I4). Evaluasi Pembelajaran dengan Pendekatan Kurikulum 2013. Bandung: Penerbit Pustaka Setia Bandung. 